\title{
REMINERALIZATION POTENTIAL OF A CARBAMIDE BLEACHING AGENT
}

\author{
Borislavova Marinova-Takorova Mirela, ${ }^{1}$ Anastasova Radostina, ${ }^{2}$ Panov Vladimir ${ }^{3}$ \\ ${ }^{1}$ Department of Conservative Dentistry, Faculty of Dental Medicine, Medical University, Sofia, Bulgaria \\ ${ }^{2}$ Department of Conservative Dentistry and oral pathology, Faculty of Dental Medicine, \\ Medical University, Varna, Bulgaria \\ ${ }^{3}$ Department of Conservative Dentistry oral pathology, Faculty of Dental Medicine, \\ Medical University, Varna, Bulgaria
}

Primljen/Received 19. 01. 2016. god.

Abstract: Background: Bleaching has gradually became a popular procedure for people searching for aesthetic improvement. The aim of this in vitro study was to investigate the effect of bleaching with $45 \%$ carbamide peroxide on the level of mineralization of enamel, using laser fluorescence.

Materials and methods: Sixty extracted human teeth were treated with $45 \%$ carbamid peroxide (Opalescence, Ultradent), 4 consecutive days for one hour each day. The effect of the bleaching agent on the level of mineralization of enamel was measured with DIAGNO dent pen. The statistical method we use was descriptive analysis.

Results: The average values, measured before the applications of the carbamid peroxide were 6.33 . On the first day they were 5.41 , on the second 5.38 , on the third 5.11 and 5.35 on the forth.

Conclusion: There was observed a slight remineralization effect due to the incorporated $\mathrm{Ca}^{2+}$ and $\mathrm{F}^{-}$ ions in the bleaching agent that we have used.

Key words: bleaching, DIAGNO den pent, carbamide peroxide.

\section{INTRODUCTION}

During the last decade bleaching has gradually become a popular procedure for people searching aesthetic improvement. Despite of the changes in the composition of the bleaching agents a debate concerning their effect on human enamel still exists. They contain either hydrogen peroxide or carbamide peroxide. The peroxide is decomposed into free radicals, which break down large pigmental molecules, thus altering light absorption and eliminating or reducing stains (1). This,
Prihvaćen/Accepted 07. 03. 2016. god.

according to some authors leads to such side effects as demineralization of the periphery of enamel prisms, increased enamel porosity, erosion $(2,3)$. It also affects the organic composition of enamel (4). Different types of mineralizing agents were recommended to be used during the bleaching procedures or afterwards in order to reduce these side effects $(5,6)$.

There has been used a variety of methods for the determination of the demineralization and remineralization that occur during bleaching - confocal laser microscopy, microhardness tests, microradiography, iodide permeability and surface microhardness, scanning electron microscopy, etc. $(3,6,7,8)$.

\section{AIM}

The aim of the presented study was to evaluate in vitro the effect of bleaching with $45 \%$ carbamide peroxide on the level of mineralization of enamel, using laser fluorescence.

\section{MATERIAL AND METHODS}

Sixty extracted human teeth were treated with 45\% carbamide peroxide (Opalescence, Ultradent), 4 consecutive days for one hour each time. The effect of the bleaching agent on the level of mineralization of enamel was measured with DIAGNOdent pen. The protocol of the conducted study was the following:

1. Areas with intact smooth enamel surface with sizes $2 \mathrm{~mm} / 2 \mathrm{~mm}$ were selected on each tooth using DIAGNOdent pen.

2. The teeth were covered with acid resistant varnish except for the selected areas. 
3. DIAGNOdent pen was used to register the values of the enamel surfaces left uncovered with the varnish before the bleaching.

4. The enamel was treated with $45 \%$ carbamide peroxide (Opalescence, Ultradent), four consecutive days for one hour each time. The changes in the level of mineralization of the selected areas were measured after each bleaching period.

The statistical method we use was descriptive analysis.

\section{RESULTS}

The average values, measured before the applications of the carbamide peroxide were 6.33. Average values of 5.41 were registered after bleaching of the unprotected enamel surfaces on the first day. Decrease in the measured data was registered for thirty-seven of the enamel surfaces, increased - for eight and with no change - for fifteen. On the second day forty-two teeth had decreased values, two - increased and sixteen - no changes. The average value for the investigated surfaces was 5.38. For the last two days of our experiment the number of the teeth with decreased values became even higher. They were forty-eight on the third day and forty-five on the fourth day. Only one tooth on the third day and five teeth on the fourth day had increased values. The number of teeth without changes was eleven and ten respectively. The average values, measured on the third day were 5.11 and 5.35 on the forth (Table 1 and Table 2).

\section{DISCUSSION}

DIAGNOdent is a $655 \mathrm{~nm}$ diode laser, allowing detection of non-cavitated, occlusal pit and fissure tooth decay and smooth surface caries in an early stage. It measures the laser fluorescence of the mineral structure of the tooth. At the specific wavelength that DIAG-
NOdent laser operates, healthy tooth structure exhibits little or no fluorescence, resulting in very low scale readings on the display. However, decayed tooth tissue exhibits fluorescence, proportional to the degree of the lost tooth structure, resulting in elevated scale readings on the display of the DIAGNOdent. According to one of the theories concerning the way the device operates, when infrared light reaches porosities due to demineralization in tooth structures, a fluorescent light of different wavelength is stimulated. The other explanation of the way of action of DIAGNOdent is that the products of the bacterial metabolism lead to changes in the fluorescence of tooth structures (9). In the conducted study the observed changes in the measured values is due only to the influence of the bleaching agent on the level of mineralization and not to the presence of bacterial products.

DIAGNOdent pen is a device that according to different authors could be used in studies evaluating the level of mineralization of tooth tissues $(10,11,12,13)$.

There are also some studies that found out that demineralization of enamel did not affect the DIAGNOdent measurements and changes in measurements are due to bacteria, but they are dependent on bacterial metabolites rather than the type of bacteria (14).

Concerning the treatment planning, according to the manufacturer, values between $10-15$ require no active care or treatment, values between 15-30 require preventative or operative care, depending on the patient's caries risk and values of $30+$ require both operative and preventative care. So the bleaching agent did not lead to changes in the enamel that could need preventive treatment.

The bleaching agent that was used in the presented study (Opalescence Boost PF 40\%, Ultradental) contains potassium nitrate and fluoride. Potassium nitrate is added in order to reduce sensitivity. Fluoride is added to help remineralization and strengthen enamel. According to some studies on the effect of bleaching

Table 1. Number of exanimated teeth

\begin{tabular}{|c|c|c|c|}
\hline Bleaching day & $\begin{array}{c}\text { No of teeth with } \\
\text { decreased values }\end{array}$ & $\begin{array}{c}\text { No of teeth with } \\
\text { increased values }\end{array}$ & $\begin{array}{c}\text { No of teeth with no } \\
\text { change }\end{array}$ \\
\hline 1 & 37 & 8 & 15 \\
\hline 2 & 42 & 2 & 16 \\
\hline 3 & 48 & 1 & 11 \\
\hline 4 & 45 & 5 & 10 \\
\hline
\end{tabular}

Table 2. Average values measured with DIAGNOdent pen before and after bleaching

\begin{tabular}{|c|c|c|c|c|}
\hline $\begin{array}{c}\text { Before } \\
\text { bleaching }\end{array}$ & $\begin{array}{c}\text { First day } \\
\text { bleaching }\end{array}$ & $\begin{array}{c}\text { Second day } \\
\text { bleaching }\end{array}$ & $\begin{array}{c}\text { Third day } \\
\text { bleaching }\end{array}$ & $\begin{array}{c}\text { Forth day } \\
\text { bleaching }\end{array}$ \\
\hline 6.33 & 5.41 & 5.38 & 5.11 & 5.38 \\
\hline
\end{tabular}


agents the addition of fluoride does not affect the gel's whitening efficacy (15), but it could eventually provide remineralization properties to the gel $(16,17)$. Despite of the treatment with the bleaching agent the level of mineralization of sound enamel increased in $60.18 \%$ of the teeth on the first day and reached $70.5 \%$ of the teeth on the fourth day. This demonstrates that the addition of agents restoring the mineral content of tooth tissues into the bleaching agents is effective and could eventually lead to a satisfactory reduce of the post-bleaching side effects.

\section{CONCLUSIONS}

Based on the results, obtained from the presented study it may be concluded that the studied bleaching agent has a slight remineralization effect due to the incorporated fluoride ions. No demineralization was observed.

\section{Conflict of interests}

The authors declare there is no conflict of interests.

\title{
Sažetak
}

\section{REMINERALIZIRAJUĆI POTENCIJAL KARBAMIDA KAO AGENSA ZA IZBELJIVANJE ZUBA}

\author{
Borislavova Marinova-Takorova Mirela, ${ }^{1}$ Anastasova Radostina, ${ }^{2}$ Panov Vladimir ${ }^{3}$ \\ ${ }^{1}$ Department of Conservative Dentistry, Faculty of Dental Medicine, Medical University, Sofia, Bulgaria \\ 2 Department of Conservative Dentistry and oral pathology, Faculty of Dental Medicine, Medical University, Varna, Bulgaria \\ ${ }^{3}$ Department of Conservative Dentistry oral pathology, Faculty of Dental Medicine, Medical University, Varna, Bulgaria
}

Uvod: Izbeljivanje zuba je danas popularna estetska procedura. Cilj ove in vitro studije je ispitati efekat izbeljivanja 45\% karbamid-peroksida u odnosu na mineralizaciju gleđi upotrebom lasera.

Materijal i metode: Šezdeset izvađenih ljudskih zuba tretirano je 45\% karbamid-peroksidom (Opalescence, Ultradent) tokom četiri uzastopna dana, po sat vremena dnevno. Efekat izbeljivanja na nivou minerelizacije gleđi je meren DIAGNO denta penom. Statistički su podaci obrađeni deskriptivnom analizom.

\section{REFERENCES}

1. Joiner A. The bleaching of teeth: a review of the literature. J Dent. 2006; 34(7): 412-9.

2. Basting RT, Rodrigues AL, Serra MC. Micromorphology and surface roughness of sound and demineralized enamel and dentin bleached with a $10 \%$ carbamide peroxide bleaching agent. Am J Dent. 2007; 20(2): 97-102.

3. Berger SB, Pavan S, Dos Santos PH, Giannini M, Bedran-Russo AK. Effect of bleaching on sound enamel and with early artificial caries lesions using confocal laser microscopy. Braz Dent J. 2012; 23(2): 110-5.

4. Hegedüs C, Bistey T, Flóra-Nagy E, Keszthelyi G, Jenei A. An atomic force microscopy study on the effect of bleaching agents on enamel surface. J Dent. 1999; 27(7): 509-15.

5. Yu D, Gao S, Min J, Zhang Q, Gao S, Yu H. Nanotribological and nanomechanical properties changes of tooth after bleaching and remineralization in wet environment. Nanoscale Res Lett. 2015; 10(1): 463.

6. Penumatsa NV, Kaminedi RR, Baroudi K, Barakath O. Evaluation of remineralization capacity of casein phosphopepti-
Rezultati: Prosečne vrednosti, merene pre aplikacije karbamid-peroksidom, su bile 6,33. Prvog dana nakon aplikacije bile su 5,41, drugog dana 5,38, trećeg dana 5,11 i 5,35 četvrtog dana.

Zaključak: Uočen je blag remineralizirajući efekat usled inkorporiranih $\mathrm{Ca}^{2+} \mathrm{i} \mathrm{F}^{-}$jona agensa za izbeljivanje koji smo koristili.

Ključne reči: izbeljivanje, DIAGNO denta pen, karbamid-peroksid.

de-amorphous calcium phosphate on the carbamide peroxide treated enamel. J Pharm Bioallied Sci. 2015; 7(Suppl 2): S583-6.

7. Gjorgievska E, Nicholson JW. Prevention of enamel demineralization after tooth bleaching by bioactive glass incorporated into toothpaste. Aust Dent J. 2011; 56(2): 193-200.

8. White DJ, Faller RV, Bowman WD. Demineralization and remineralization evaluation techniques-added considerations. J Dent Res.1992; 71(spec No): 929-33.

9. Amaechi BT. Emerging technologies for diagnosis of dental caries: The road so far. J Appl Phys. 2009; 105(10): 102047.

10. Bahrololoomi Z, Musavi SA, Kabudan M. In vitro evaluation of the efficacy of laser fluorescence (DIAGNOdent) to detect demineralization and remineralization of smooth enamel lesions. J Conserv Dent. 2013; 16(4): 362-6.

11. Mendes FM, Nicolau J, Duarte DA. Evaluation of the effectiveness of laser fluorescence in monitoring in vitro remineralization of incipient caries lesions in primary teeth. Caries Res. 2003; 37(6): 442-4.

12. Diniz MB, Paes Leme AF, Cardoso Kde S, Rodrigues JdeA, Corderio Rde C. The efficacy of laser fluorescence system to detect in vitro demineralization and remineralization of 
smooth enamel surfaces. Photomed Laser Surg. 2009; 27(1): $57-61$.

13. Moriyama CM, Rodrigues JA, Lussi A, Daniz MB. Effectiveness of fluorescence-based methods to detect in situ demineralization and remineralization on smooth surfaces. Car Res. 2014; 48(6): 507-14.

14. Astvaldsdóttir A, TranFus S, Karisson L, Peter Holbrook W. DIAGNOdent measurements of cultures of selected oral bacteria and demineralized enamel. Acta Odontol Scand. 2010; 68(3): 148-53.

\section{Correspondence to/ Autor za korespondenciju}

Mirela Marinova-Takorova

Faculty of Dental Medicine

Department of Conservative Dentistry

1, G. Sofiiski Blvd.

1606 Sofia, Bulgaria

marinova.takorova@gmail.com

phone: +359888440582
15. Gladwell J, Simmons D, Wright JT. Remineralization potential of a fluoridated carbamide peroxide whitening gel. J Esthet Restor Dent. 2006; 18(4): 206-12.

16. Attin T, Betke H, Schippan F, Wiegand A. Potential of fluoridated carbamide peroxide gels to support post-bleaching enamel re-hardening. J Dent. 2007; 35(9): 755-9.

17. Bollineni S, Janga RK, Venugopal L, Reddy IR, Babu PR, Kumar SS. Role of fluoridated carbamide peroxide whitening gel in the remineralization of demineralized enamel: An in vitro study. J Int Soc Prev Community Dent. 2014; 4(2): 117-21. 